\title{
Taxonomical analysis of closely related species of Chara L. section Hartmania (Streptophyta: Charales) based on morphological and molecular data
}

\author{
Jacek URBANIAK ${ }^{* 1} \&$ Hidetoshi SAKAYAMA ${ }^{2}$ \\ *lDepartment of Botany and Plant Ecology, Wroctaw University of Environmental and Life Sciences, pl. Grun- \\ waldzki 24a,50-363 Wroctaw, Poland; Corresponding authore-mail: jacek.urbaniak@upwr.edu.pl \\ ${ }^{2}$ Department of Biology, Graduate School of Science, Kobe University, 1-1 Rokkodai, Nada-ku, Kobe 657- \\ 8501, Japan
}

\begin{abstract}
In this study, five charophyte species belonging to the genus Chara L. section Hartmania, collected in Poland, were examined to determine their taxonomic status. Oospore dimensions of all investigated species differed significantly in their length, width and number of striae. However, no clear differences were found in the case of the oospore wall ornamentation that could be used for clear differentiation of the studied species. Detailed SEM images showed that the ornamentation on the oospore wall is not species specific, and also does not allow for differentiation of the species. Moreover, molecular phylogenetic analyses based on the matK and $a t p B$ DNA sequences reveal that the five studied species of section Hartmania are closely related and exhibit low genetic variation. Both types of analyses, based on oospore morphology and DNA barcoding, suggest a close phylogenetic relationship among the investigated species. The low levels of variability between species suggest that they had a relatively recent common ancestor, and probably exhibit a still incomplete, speciation process.
\end{abstract}

Key words: atpB, Chara, Characeae, Charophyta, Europe, matK, molecular phylogeny, morphology, oospore, taxonomy

\section{INTRODUCTION}

Charophytes (stoneworts, Charales, Charophyta) are a group of Streptophyta inhabiting both fresh and brackish water all over the world and form a distinct group, characterized by their unique types of vegetative and reproductive organs (WOOD \& IMAHORI 1965; URBANIAK \& GĄMBKA 2014; RoMANOv et al. 2015). Members of the charophytes produce female organs that consist of a large egg cell surrounded by an envelope of five left-twisted spiral cells. After fertilisation, rapid changes occur in the walls of the newly formed zygote and the sterile ensheathing cells. This results in the formation of a thick wall that is multilayered, pigmented and often overlaid by calcite. This structure is known as the oosporangium, and the resting zygote enclosed in it forms an oospore that consists of eight wall layers (Leitch 1989; John et al. 1990). Two of these are the primary wall layers and the remainder are the secondary wall layers. The outermost layer of the oospore wall is deposited by the spiral cells and is called the ornamentation layer or ectosporostine, which has chemical properties similar to sporopollenin (HORN AF RANTZIEN
1956; Leitch 1989). Differential deposition in this layer of the wall results in specific oospore surface ornamentation and characteristic oospore morphology (e.g. length, width, number of striae, and width of the fossa). Since the taxonomic study of charophytes began, these oospore characteristics have been used to diagnose to species and/or infraspecific levels (HAAS 1994).

For species determination (distinguishing particular taxa), earlier authors mainly used qualitative vegetative characteristics such as types of cortification (diplostichous, triplostichous, and isostichous), occurrence of spine cells (aulacanthous and thylacanthous), length and clustering of spine cells (solitary, in clusters, and vertically geminate), and stipulode types (single ring, double ring, or irregular) (BRAUN \& NoRDSTEDT 1882; Olsen 1944; KRAuSE 1997). Because the thalli are often heavily affected by ecological conditions, their plasticity in ecological expression demands care when making taxonomic decisions; it is important to know the phenotypes that are environmentally induced and those that are genetically controlled (Woop \& IMAHORI 1965). Together, these varying morphological features could be the main reason for many of the transition forms that commonly exist. 
Because of the high plasticity of charophytes and wide range of morphological variations, WoOD (1962), WOOD \& IMAHORI (1965), interpreted the genus Chara as being composed of only 18 macrospecies, lumping together approximately 400 taxa previously described as separate species (MeIERs et al. 1999). Therefore, many species were relegated to the level of infraspecific taxa (subspecies, varieties and forms) and synonyms. On the other hand, recent studies (JoHN et al. 1990; Krause 1997; URBaniaK 2010; URBAniaK \& GAqmBKA 2014) have suggested that the genus Chara is made up of many microspecies that can be regarded as a complex of very closely related species distinguished by a small number of morphological characteristics such as spine cells, cortification, or stipulodes. Regarding species, these two interpretations could be a reason for the lack of objective methods for determining the characteristics that actually serve to delimit various species within the genus (Boegle et al. 2007; URBANiAK 2009). Recent chromosomal and scanning electron microscopy (SEM) studies of the oospore wall ornamentation and dimensions have been used for species delimitation in the genus Chara, suggesting that both methods can be helpful in taxonomic decisions on species (LEITCH 1989; John \& Moore 1987; UrbaniaK 2011b; UrbaNIAK \& BLAŽENČIĆ 2012; Urbaniak et al. 2012; CASANOVA 2015). Detailed statistical analyses of oospore dimensions have also been studied by MANDAL et al. (2002) and Urbaniak (2009). SAKAyAma et al. (2009, 2015) and Perez et al. 2014) showed that the combination of different types of data (SEM oospore morphology and molecular data) can be more informative than when taken separately, and can be used for taxonomic distinction, especially in closely related species of the genus Nitella or Tolypella.

For the genus Chara, molecular phylogenetic analyses, based on chloroplast and nuclear DNA gene sequences, together with analyses of morphological characteristics, have also been carried out to resolve the relationships at species or genic level (McCourT et al. 1996; Meiers et al. 1999; SANDERs et al. 2003; SAKAYAMA et al. 2009; SCHNEIDER et al. 2015; NowAK et al. 2016). By contrast, in the same way using combined morphological characteristics of the species and analysis of about 6214 bp, NowAK et al. (2016) coudl not separate Chara individuals and all of the studied species. This was also not possible by means of several barcode markers on a much larger data set (SCHNEIDER et al. 2016) using amplified fragment length polymorphism (AFLP) analysis, which has been used to determine the taxonomy of the genus Chara (URBANIAK \& Cомвік 2013). Because of these difficulties, we performed this study focussing on four freshwater species (two diplostichous aulacanthous species (Chara hispida L. and $C$. rudis A.BrAUN) and two diplostichous thylacanthous species ( $C$. intermedia A.Braun and $C$. polyacantha A.BRAUN) and one brackish water species (a diplostichous thylacanthous species, C. baltica BRU-
ZELIUS, in transition to slightly isostichous), which belongs to the section Hartmania. Characteristics of these species were analysed by combined SEM microscopy of oospore wall ornamentation and molecular phylogeny based on two chloroplast DNA markers (atp B and $m a t \mathrm{~K}$ ). The objectives of our study were to 1) characterise the inter- and intra-specific variations of oospores from different populations, 2) assess the relative magnitude of variations within and among species in oospore dimensions, and 3) resolve the phylogenetic relationships within the genus Chara section Hartmania based on the comparison of molecular data with data on oospore morphology. Additionally, we analysed how the chemicals used in procedures for oospore cleaning (acetolysis) influence oospore dimensions.

\section{MAterials AND MEthodS}

Samples were collected directly from natural populations where charophytes are known to grow. For oospore analysis, oospores were collected from the sediment and in several cases, from herbarium collections (Table 1). The identification of species written on the herbarium sheets and those collected from the field were verified according to WOOD \& IMAHORI (1965), KRAUSE (1997). Species names are followed according to URBANIAK \& GĄmBKa (2014).

Oospore analysis. After collection, all oospores were cleaned using the method described in detail by RAY et al. (2001) or URBANIAK (2011a) with an acetolysis procedure similar to that described by ERDTMAN (1960) for the preparation of pollen grains for light microscopy or SEM investigations. The mature (black or dark brown) oospores were separated carefully from the sediment or from the sheets using forceps. The spiral cells were removed and the oospores were then cleaned using dilute detergent (detergent: water $=1: 10$ ) in a water bath at $45^{\circ} \mathrm{C}$ for 12 hours. The oospores were then washed several times in distilled water, centrifuged at 300 r.p.m. for $5 \mathrm{~min}$, then the water decanted off and glacial acetic acid was added. After $10 \mathrm{~min}$, the oospores were centrifuged for a further $5 \mathrm{~min}$, the glacial acetic acid was decanted and an acetolysis mixture (acetic anhydride and concentrated sulphuric acid, ratio 9:1) was added (JoHN \& Moore 1987). The rest of the acetolysis procedure was the same as that described by ERDTMAN (1960). The cleaned oospores were dried after a final washing in $96 \%$ ethanol and mounted on brass stubs with double-sided adhesive tape, sputter coated with gold, and viewed using an LEO 435 VP (ZEISS, Carl Zeiss, Oberknochen, Germany) or HITACHI S-4700 (Hitachi, Tokyo, Japan) scanning electron microscope (SEM). The oospore wall ornamentation pattern was described following the terminology used by JoHN \& MoOre (1987), JoHn et al. (1990) and LeITCH et al. (1990). The length, width, number of striae and width of fossa of all available oospores per population were measured after acetolysis using a Zeiss Axioscop light microscope (ZEISS, Carl Zeiss, Oberknochen, Germany). All investigated oospores mounted on brass stubs are available from Jacek Urbaniak.

In order to allow for the morphological analysis of oospore differences (length, width, number of striae and fossa width) between taxa and single populations, min-max 


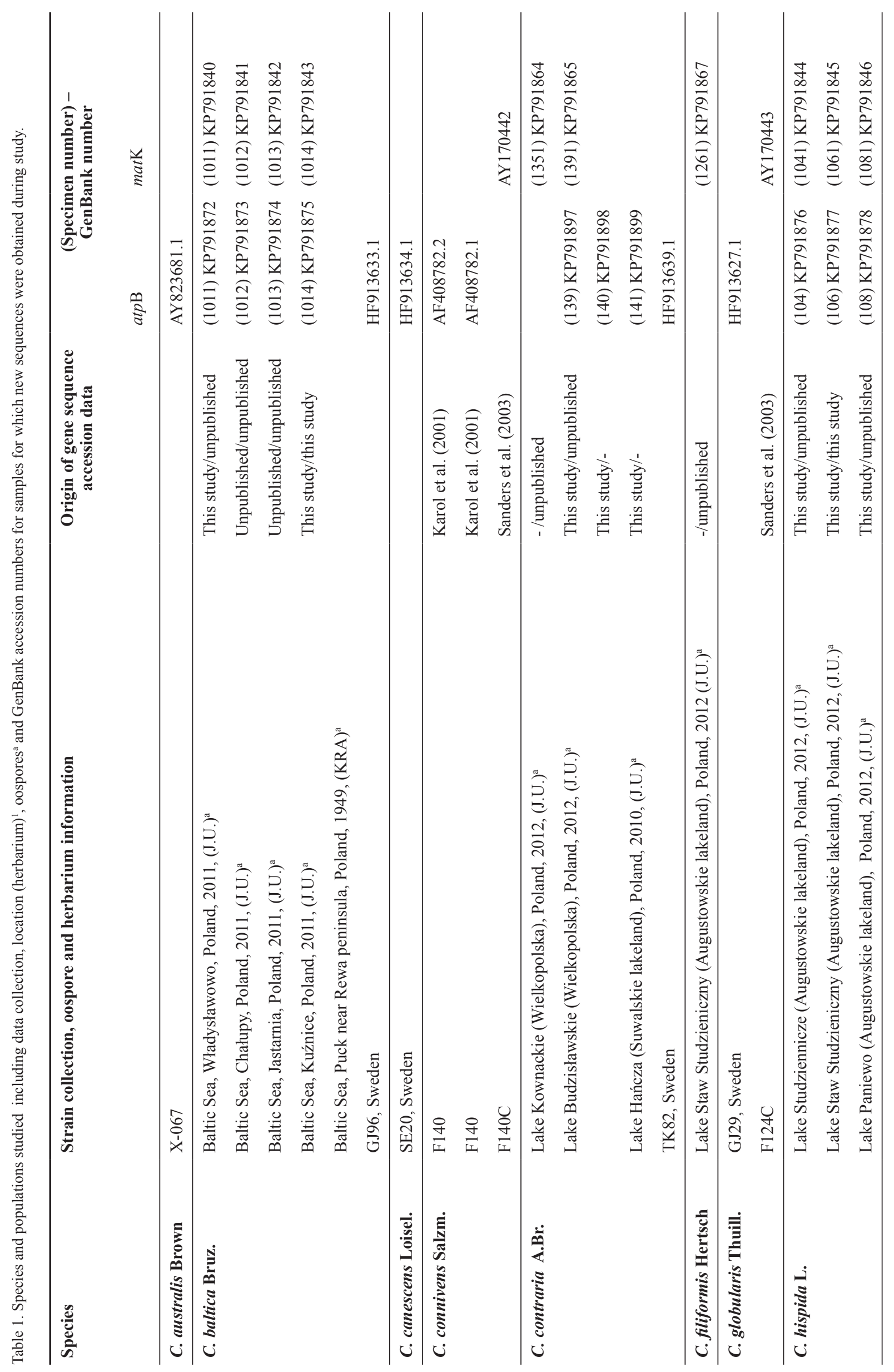




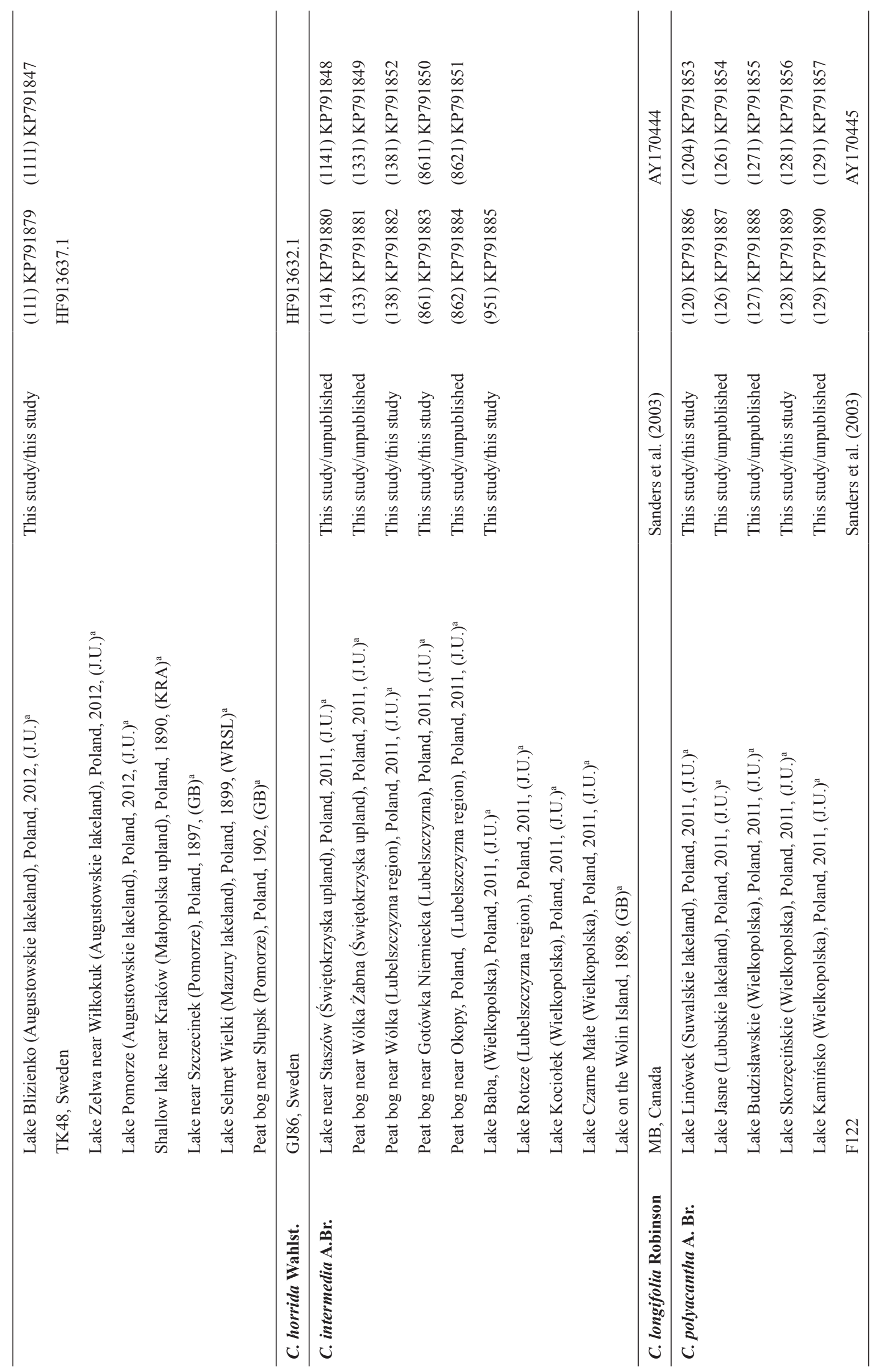




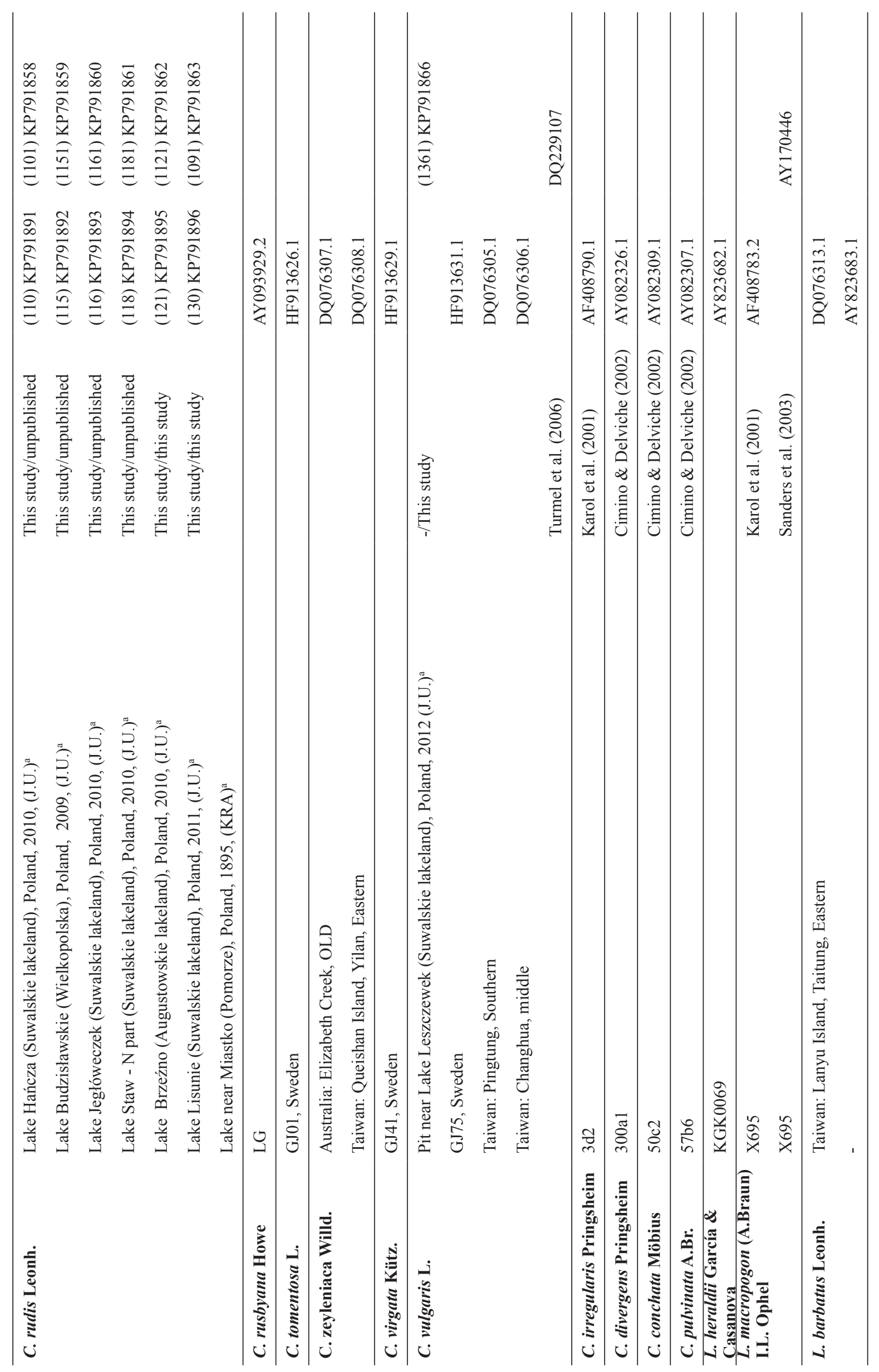




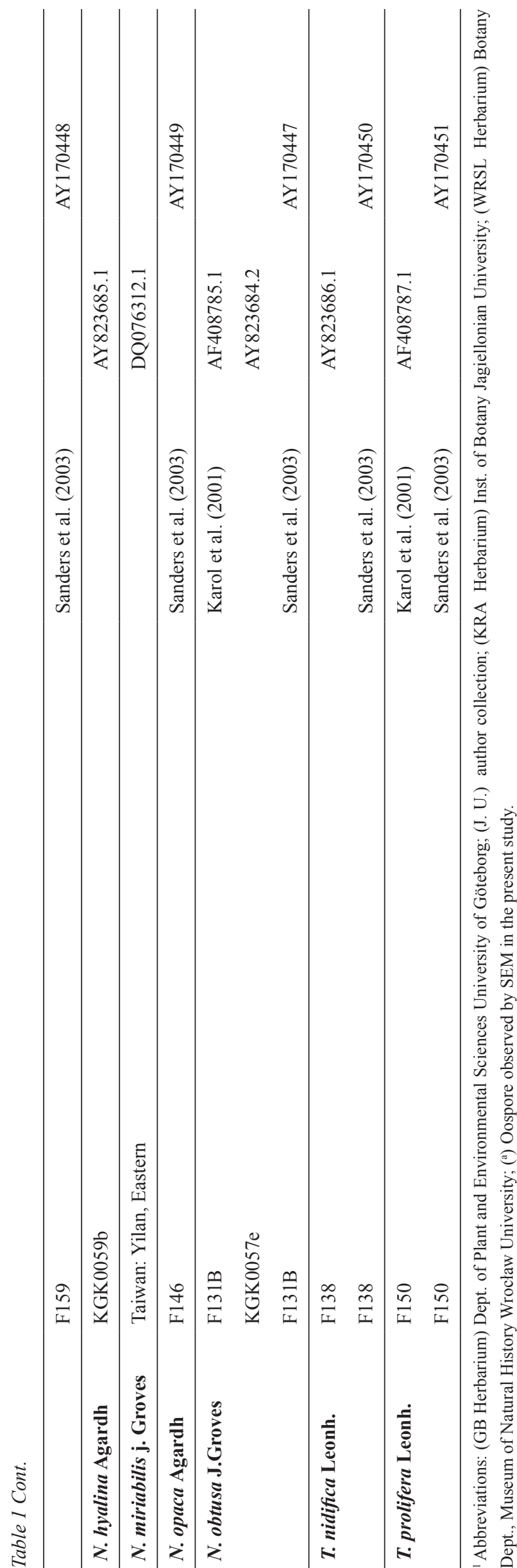

ranges, means and standard deviation were calculated and cluster analysis (Ward method, Euclidean distance) was carried out. Statistical differences were assessed using the analysis of variance (ANOVA) and parametric post hoc test of least significant difference (LSD). All statistical analyses were performed using the Statistica 9.1 package (StatSoft 2010, Tulsa, OK United States). All the investigated oospores as well as herbarium material are available from the author or the herbaria listed in Table 1. In total, about 1400 oospores were measured for this analysis.

Additionally, according to BLumE et al. (2009), numerous observations of oospore differences exist in various papers and monographs (HAAS 1994; VEDDER 2004; BLumE et al. 2009), however, only little is known about the influence of oospore cleaning (acetolysis) procedures on these features. This was checked in an additional study which evaluated the entire preparation procedure with chemical treatment during cleaning and showed how this procedure influenced oospores. Three groups of $C$. intermedia oospores were collected for the experiment from the sediment at three different localities and measured before and after the cleaning/acetolysis procedure. The first group $(n=62)$ of oospores was dried immediately after collection and measured as dry before treatment. Oospores from the second group $(n=156)$ were stored in wet sediment in the refrigerator and in distilled water before the experiment started and measured as wet. Similarly, the third group of oospores $(\mathrm{n}=107)$ were stored under wet conditions and treated with $10 \%$ hydrochloric acid before the first measurements, which is a commonly used procedure for removing calcium carbonate from oospores. The results were tested using the non-parametric Wilcoxon's test for tied ranks.

Molecular analysis. Three to four individuals were collected per population and each was examined separately (Table 1). Fresh plant material was collected in the field, placed in glass jars and quickly transported to the laboratory. To reduce the influence of alien DNA from epiphytes, large filamentous green algae were removed from young plant shoots by dissection with needles under a SMZ 800 stereomicroscope (Nikon; Tokyo, Japan) and were cultured in laboratory conditions (at room temperature with light from a north-facing window) in jars filled with filtered lake water (20-30 $\mu \mathrm{m}$ mesh). Only fresh, newly grown parts were used for analysis. Total genomic DNA was isolated from fresh tissue using freeze dried, powdered material using the DNeasy Plant Mini Kit (Qiagen; Hilden, Germany), according to the manufacturer's protocol. Cells were disrupted using Mixer Mill MM400 (Retsch; Haan, Germany) and liquid nitrogen. The quality and quantity of the DNA was determined using a fluorometer (Eppendorf; Hamburg, Germany). The integrity of the extracted DNA was estimated on a $1 \%$ TBE agarose gel.

The PCR of the atpB and matK genes was performed as four and two (respectively) overlapping fragments in a Veriti gradient Thermal Cycler (Applied Carlsbad, CA, USA). The PCR amplification and sequencing atpB gene was accomplished using the primers described previously by SAKAYAMA et al. (2004) and matK using universal primers designed by SANDERS et al. (2003). Each $20 \mu \mathrm{l}$ reaction contained $10 \mathrm{mM}$ each of dATP, dCTP, dGTP and dTTP; $0.5 \mu \mathrm{M}$ of each primer, 
$4.0 \mu 15 \times$ reaction buffer, $0.2 \mu 1$ Phusion Hot Start II HF DNA Polymerase (Thermo Scientific, Waltham, MA, USA.) and $1.0 \mu 1$ of total genomic DNA. The PCR cycle consisted of an initial denaturation of $98^{\circ} \mathrm{C}$ for $20 \mathrm{~s}$, followed by 32 cycles of $98^{\circ} \mathrm{C}$ for $5 \mathrm{~s}$, adequate annealing temperature tested with the gradient method for $15 \mathrm{~s}$, and $72^{\circ} \mathrm{C}$ for $30 \mathrm{~s}$, with a final extension of $5 \mathrm{~min}$ at $72^{\circ} \mathrm{C}$. The PCR products were examined for correct length, yield, and purity under UV light on $1 \%$ agarose gels stained with ethidium bromide. PCR products were purified prior sequencing reaction using the High Pure PCR Product Purification Kit (Roche Diagnostic, Mannheim, Germany) and sequenced using the amplification primers.

All molecular analysis has been done at Department of Botany and Plant Ecology Wrocław University of Environmental and Life Sciences except of sequencing, post reaction cleaning and reading which were done by Genomed sequencing service (Warsaw, Poland) using an ABI 377XL Automated DNA Sequencer (Applied Biosystems, Carlsbad, CA, USA).

Sequence alignment and phylogenetic analyses. The $a t p B$ and matK DNA sequence data were analyzed separately. For the $a t p \mathrm{~B}$ gene phylogeny, some additional sequences from the genus Chara, Lamprothamnium J.Groves, Lychnothamnus A.Braun, Nitellopsis Hy, Nitella and Tolypella A.Braun were obtained from GeneBank (Table 1, Fig. 41). In the phylogenetic analyses, four Coleochaete species (Coleochaete irregularis Pringsheim, C. divergens Pringsheim, C. conchata K.MöBIUs and C. pulvinata A.BRAUN) were selected as an outgroup because recent phylogenetic studies have demonstrated the monophyly of the Characeae within the Streptophyta Charophyceae sensu MatTox \& STEwART (1984) and land plants and the close relationship between the Characeae and Coleochaete species (McCourt et al. 1996, 1999; SAKAYAMA 2008; WodNIOK et al. 2011; LAURIN-LEMAY et al. 2012). The $a t p B$ DNA sequences analysed in this study were 1029 bp and correspond to position 241-1269 of the Chara vulgaris atpB gene (TURMEL et al. 2006).

Prior to the phylogenetic analyses, the atpB DNA sequences were aligned using Clustal W (THOMPSON et al. 1994), and the alignment was subsequently adjusted by eye. A tree was constructed by the maximum likelihood (ML) method using PhyML 3.0 (Guindon \& Gascuel 2003). Kakusan 4 (TANABE 2011) was used to identify the sequence evolution model that fit the dataset using Akaike's Information Criterion (AIC). The bootstrap proportions (BP) (FELSENSTEIN 1985) used for ML analyses (with the GTR $+\mathrm{G}$ model selected by Kakusan4) were calculated based on 100 replicates of heuristic searches with the best of the nearest neighbor interchange (NNI) and subtree pruning regrafting (SPR) branch-swapping algorithms. The Bayesian inference (BI), maximum parsimony (MP) and neighbor-joining (NJ) trees were also constructed and compared the topologies of the obtained trees to establish and validate the phylogenetic position of the studied species. The BI analyses were performed using MrBayes 3.1.2. (Ronquist \& HuelsenbeCK 2003). The substitution models used for each codon position of the $a t p \mathrm{~B}$ gene in the BI analyses were GTR $+\mathrm{G}$ (1st codon position), GTR $+\mathrm{I}$ (2nd codon position), and $\mathrm{GTR}+\mathrm{I}+\mathrm{G}$ (3rd codon position), which were estimated based on AIC and selected by MrModeltest 2.3 (Nylander et al. 2004) using PAUP* 4.0b10 (SwOFFord 2002). The parameters of the substitution models for each codon position were unlinked. The Markov chain Monte Carlo iteration process was stopped at 1,000,000 generations. The first $25 \%$ of generations were discarded as burn-in, whereas the remaining trees were used to calculate a $50 \%$ majorityrule tree and to determine the posterior probabilities (PP) of individual branches. The average standard deviations of the split frequencies were below 0.01 , indicating convergence of the iterations. BPs for MP analyses based on 1,000 replications of full heuristic searches with the tree-bisection-reconstruction (TBR) branch-swapping algorithm, and those for NJ analyses (SAIto \& NeI 1987) under the JC model (Jukes \& CANTOR 1969) based on 1,000 replications, were conducted using PAUP* 4.0b10 (SWOFFORD 2002).

In case of matK gene, DNA sequences of C. vulgaris, C. connivens, C. globularis, C. longifolia, Laprothamnium macropogon, Nitellopsis obtusa and Lychnothamnus barbatus were obtained for phylogenetic analysis from GeneBank (Fig. 42). Three species of the genera Nitella and Tolypella (Nitella opaca, Tolypella nidifica and T. prolifera) (Fig. 42) were selected as an outgroup because recent phylogenetic studies demonstrated that the tribe Chareae is monophyletic within the Charales (McCourt et al. 1996, 1999; Karol et al. 2001; SAKayama et al. 2002, 2004; SANDERS et al. 2003; SAKAYAMA et al. 2008). The matK DNA sequences analysed in this study were $1203 \mathrm{bp}$ (excluding gaps) and correspond to position 79-1314 of the Chara vulgaris mat $\mathrm{K}$ gene (Turmel et al. 2006). Prior to the phylogenetic analyses, the matK gene sequences were aligned based on the amino acid translations by MUSCLE (EDGAR 2004a, 2004b) using TranslatorX (ABASCAL et al. 2010) and the gapped regions were removed. The phylogenetic trees based on the matK gene dataset were constructed using the same methods as used to construct the atp B gene trees, except in the following aspects. For ML analyses, a TVM $+\mathrm{I}+\mathrm{G}$ model was selected. For the BI analyses, GTR $+\mathrm{I}+\mathrm{G}, \mathrm{GTR}+\mathrm{G}$ and $\mathrm{GTR}+\mathrm{I}+\mathrm{G}$ models were selected for $1 \mathrm{st}$, 2nd and 3rd codon positions, respectively.

\section{Results}

\section{Influence of the cleaning procedure on oospore di- mensions}

All of the investigated oospores were measured after the cleaning/acetolysis procedure. BLumE et al. (2009) found that dry oospores can be about $5 \%$ shorter and $27 \%$ narrower than when wet, but there are no data available as to how the cleaning/acetolysis procedure can influence oospore size (prior to SEM analysis). After treatment, almost all oospores analysed in this study were significantly smaller, shorter (4.7-6.5\%) and narrower (5.0-14.0\%) than before treatment (Fig. 1, Fig. 2 ). The cleaning procedure only led to enlargement in the case of dried oospores, which increased around $2.4 \%$ in the length; however, this difference was not statistically significant.

\section{Oospore morphology}

\section{Chara baltica BRUZ.}

Synonym: $C$. hispida $\mathrm{L}$. var. baltica BRUz.

The oospores were dark brown to black, 459-936 $\mu \mathrm{m}$ long, 306-603 $\mu \mathrm{m}$ wide, with 9-13 striae and 52-88 $\mu \mathrm{m}$ fossa width (Table 2). Significant differences be- 
tween species were found using the analysis of variance test. Oospores from all investigated populations differed in their length $(\mathrm{KW}=173.6, \mathrm{p}<0.05)$, width $(\mathrm{KW}=177.1, \mathrm{p}<0.05)$, number of striae $(\mathrm{KW}=88.3, \mathrm{p}$ $<0.05)$, and width of the fossa $(\mathrm{KW}=159.4, \mathrm{p}<0.05)$. The results also showed that $C$. baltica oospores differed significantly in their length and width from the other species; the number of striae in $C$. baltica differed significantly from oospores of $C$. intermedia, $C$. polyacantha, and $C$. rudis and the fossa width differed from that of C. hispida, C. polyacantha, and C. rudis (Table 3). This seems to be supported by the cluster analysis of the oospore, in which $C$. baltica constitutes a separate branch (Fig. 3). The oospore ornamentations of $C$. baltica were smooth under low (approx. $\times 130$ $200)$ and high $(\times 1000-2000)$ magnification, without any characteristic type of ornamentation (Figs 4-8).

\section{Chara hispida L.}

Synonym: C. hispida L. var. major f. major Wood et IMAHORI

The oospores were dark brown, 414-882 $\mu \mathrm{m}$ long, 288-702 $\mu \mathrm{m}$ wide, with 7-14 striae and 33-103 $\mu \mathrm{m}$ fossa width (Table 2). Oospores from all investigated populations differed significantly in length, width, number of striae, and fossa width ( $\mathrm{p}<0.05$, Table 2$)$. Results of ANOVA showed that $C$. hispida oospores differed significantly in their length from $C$. baltica, C. intermedia and C. rudis, in width from C. baltica, $C$. intermedia and $C$. polyacantha, in the number of striae from $C$. polyacantha and $C$. rudis (Table 3). Significant differences were also found in fossa width between $C$. hispida and C. baltica, C. intermedia, $C$. polyacantha and $C$. rudis. Pustular or slightly pustular ornamentation was found on the oospores from $C$. hispida populations (Figs 9, 10, 12, 14-15); however, other types of ornamentation (such as slightly pitted, slightly granulate, smooth, and papillate patterns) were also observed (Figs 11, 13, 16-18).

\section{Chara intermedia A.BRAUN}

Synonym: C. hispida Linneaus var. major f. intermedia (A.Braun) WOOD et IMAHORI

The oospores were dark brown to black, 495-873 $\mu \mathrm{m}$ long, 306-675 $\mu \mathrm{m}$ wide, with 7-14 striae and 43-103 $\mu \mathrm{m}$ fossa width (Table 2). Oospores differed significantly in length, width, number of striae, and fossa width ( $\mathrm{p}<0.05$, Table 2). Results of ANOVA showed that $C$. intermedia oospores differed significantly in length from $C$. baltica and $C$. hispida, width from $C$. baltica, C. hispida, C. polyacantha and C. rudis, number of striae from $C$. baltica, $C$. polyacantha and $C$. rudis; fossa width from C. hispida, C. polyacantha and $C$. rudis (Table 3 ). The oospores of $C$. intermedia had different types of ornamentations, from smooth (Fig.

Fig. 3 Cluster analysis of species similarity based on the oospore dimensions and wall ornamentation.

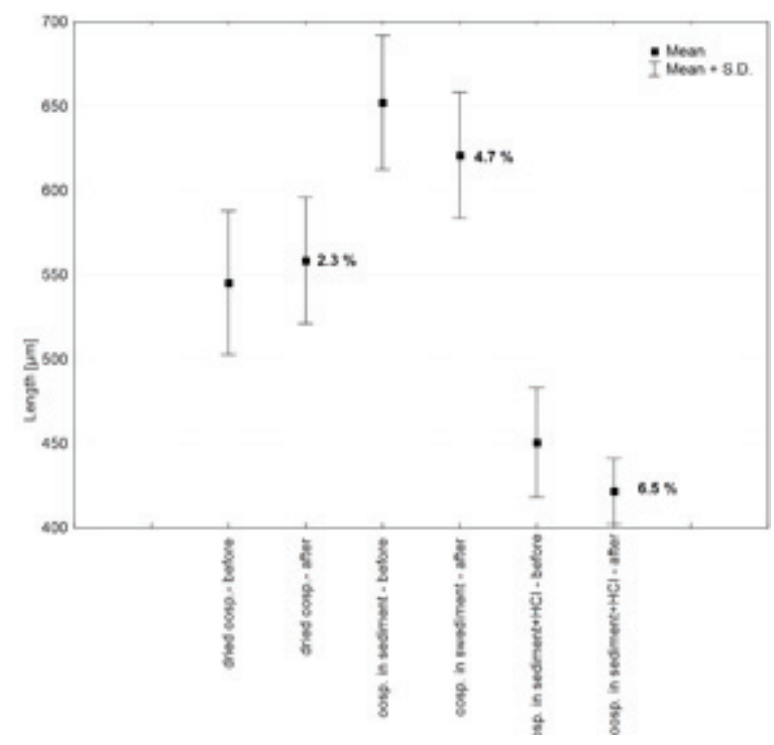

Fig. 1 Changes in the oospore length before and after cleaning and acetylation.

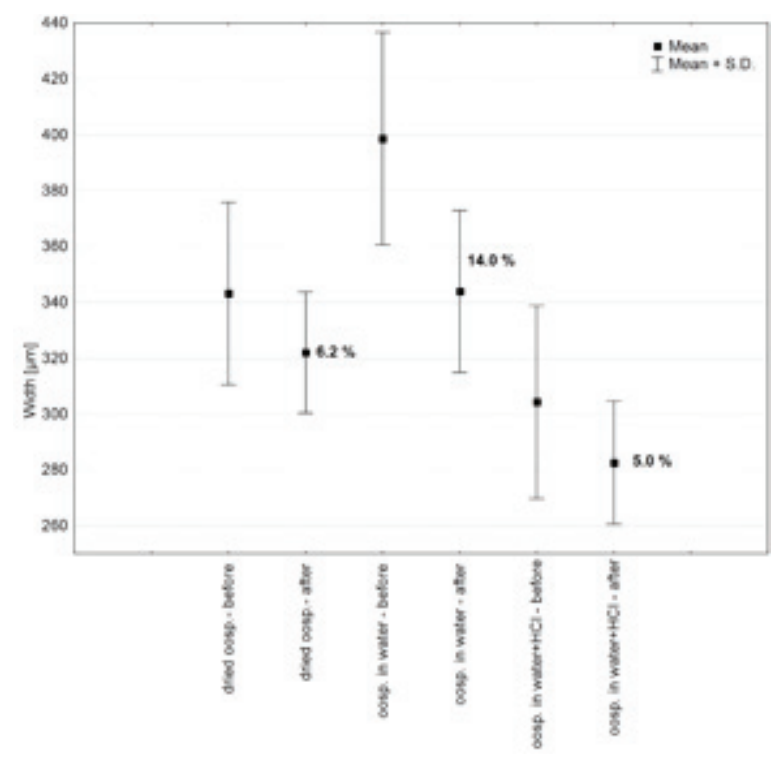

Fig. 2 Changes in the oospore width before and after cleaning and acetylation.

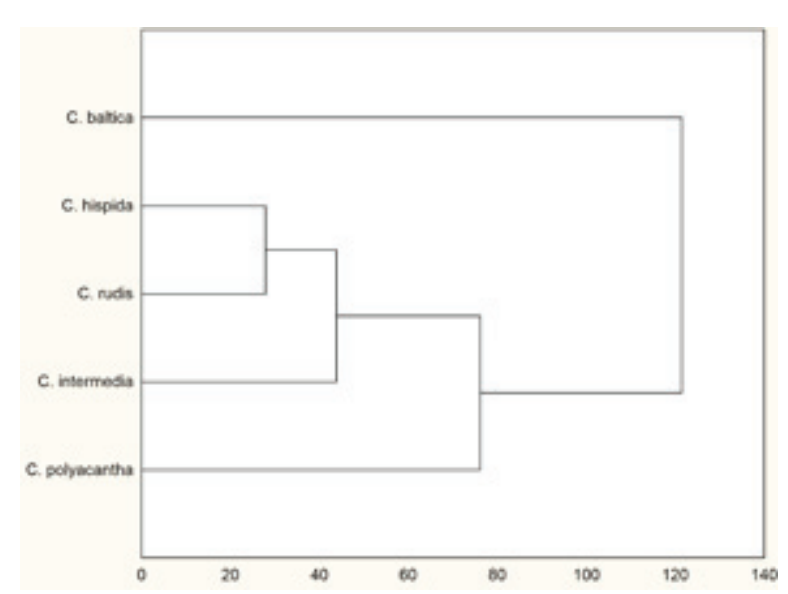


23, 24, 27, 28) to slightly granulate (Fig. 19). Pustular and slightly pustular ornamentations were also commonly observed (Fig. 20).

\section{Chara polyacantha A.BrAUN}

Synonym: C. hispida L. var. hispida f. polyacantha (A.BR.) WooD et IMAHORI

The oospores are were dark brown to black, 486-900 $\mu \mathrm{m}$ long, 279-585 $\mu \mathrm{m}$ wide, with 10-17 striae and 22-103 $\mu \mathrm{m}$ fossa width (Table 2). Oospores differed significantly in their length, width, number of striae, and fossa width ( $\mathrm{p}<0.05$, Table 2$)$. Results of ANOVA showed that $C$. polyacantha oospores differed significantly in their length from $C$. baltica, width and fossa width from $C$. baltica, $C$. hispida, $C$. intermedia and $C$. rudis and number of striae from $C$. baltica, $C$. hispida and $C$. intermedia (Table 3). The oospores of $C$. polyacantha were smooth (Fig. 29-31), slightly pitted (Fig. 33) or granulate (Fig. 32).

\section{Chara rudis (A.BRAUN) LEONH.}

Synonym: $C$. hispida L. var. major f. rudis (A.BR.) Wood et IMAHORI The oospores are were dark brown to black, 558-873 $\mu \mathrm{m}$ long, 288-732 $\mu \mathrm{m}$ wide, with 9-16 striae and 49$103 \mu \mathrm{m}$ fossa width (Table 2). Investigated oospores differed significantly in their length, width, number of striae and fossa width $(p<0.05$, Table 2$)$. Results of ANOVA showed that $C$. rudis oospores differed significantly in their length from C. baltica and C. hispida, width from C. baltica, C. intermedia, and C. polyacantha, number of striae from C. baltica, C. hispida and $C$. intermedia, fossa width from all investigated species (Table 3). In C. rudis populations, the oospores showed slightly pustular ornamentation (Fig. 34-38, 40); however, slightly granulate ornamentation was also observed (Fig. 39).

Molecular phylogenetic analyses based on the atp B DNA sequence data

A phylogenetic tree of the atpB DNA sequences based on ML analyses is shown in Fig. 41, where BPs $(\geq$ $50 \%)$ and PPs ( $\geq 0.90)$ in ML, BI, NJ or MP analyses are shown. The phylogenetic relationships we report here for the tribe Characeae were essentially consistent with previous studies (McCourT et al. 1999; SAKAYAMA et al. 2009; SCHNEIDER et al. 2015), except for relationships concerning the 31 specimens newly analyzed here (Fig. 41).

Among the species belonging to the section Hartmania, atpB DNA sequences from five species $(C$. intermedia, C. hispida, C. rudis, C. baltica and C. horrida) were identical (Fig. 41), while the sequence of $C$. polyacantha differed by one nucleotide. The sequences of our three newly analysed $C$. contraria specimen were identical to a previously published sequence of this species (Fig. 41).
Molecular phylogenetic analyses based on the matK DNA sequence data

A phylogenetic tree of the matK DNA sequences based on ML analyses is shown in Fig. 42, where BPs $(\geq$ $50 \%)$ and PPs ( $\geq 0.90)$ in ML, BI, NJ or MP analyses are shown. The resolved phylogenetic relationships within the genus Chara were essentially the same as those in the $a t p \mathrm{~B}$ gene analyses (Fig. 41) and previous studies (SANDERs et al. 2003; SchneIDER et al. 2015), (Fig. 42).

The five species of the section Hartmania $(C$. intermedia, C. hispida, C. rudis, C. baltica, and $C$. polyacantha) formed a monophyletic group with $\geq$ 99\% BP and 1.00 PP in the ML, BI, NJ and MP analyses, and are sister to the clade composed of $C$. contrar$i a$ and $C$. filiformis, supported by $\geq 88 \mathrm{BP}$ and $1.00 \mathrm{PP}$ in the ML, BI, NJ and MP analyses (Fig. 42). Within the clade of the section Hartmania, four specimens of C. intermedia (specimens 1331, 1381, 8611, and 8621) were separated from the clade composed of the four species (C. hispida, C. rudis, C. baltica, and C. polyacantha).

\section{Discussion}

Taxonomic significance of oospore dimensions and wall ornamentations within the section Hartmania

The results of numerous studies indicate that in many cases oospores alone or combined with molecular data can be used to distinguishing taxonomic differences between species from the Characeae. Such results can also be helpful in explaining the phylogenetic relationships between species (SAKAYAMA et al. 2002, 2004, 2005; UrbaniaK 2010). The large amount of data collected during this study seems to confirm the considerable variety in oospore size among populations of the same species, as has been reported previously (CASANOVA 1997; Blume et al. 2009; URBANiAK 2010; UrbANIAK \& COMBIK 2017).

Oospore dimensions from populations of section Hartmania differed significantly $(P<0.05)$ in their length, width, number of striae, and width of the fossa. However, it appears that these differences do not allow clear differentiation of the investigated species in the case of charophytes from section Hartmania. This may also explain why the identification of single taxa based only on oospore dimensions, as proposed by HaAs (1994), seems to be impossible. On the other hand, measuring a larger amount of oospores can be helpful in finding taxonomic relationships among species, as shown by Casanova (1997), URbaniaK \& BLAŽENČIĆ (2012). 
Table 2. Measurements of Chara species oospore characteristics from different populations. ${ }^{1}$

\begin{tabular}{|c|c|c|c|c|}
\hline $\begin{array}{c}\text { Population studied / } \\
\text { no. of } \\
\text { investing. } \\
\text { oospores }\end{array}$ & Length & Width & Number of striae & Fossa width \\
\hline$(n)$ & \multicolumn{4}{|c|}{ min. - max. mean \pm standard deviation } \\
\hline \multicolumn{5}{|c|}{ C. baltica } \\
\hline 39 & $702-828,759 \pm 26$ & $468-567,531 \pm 27$ & $9-12,11 \pm 1$ & $55-82,66 \pm 4$ \\
\hline 36 & $459-747,617 \pm 92$ & $306-540,413 \pm 89$ & $9-11,10 \pm 1$ & $52-77,61 \pm 7$ \\
\hline 37 & $855-936,888 \pm 20$ & $504-576,545 \pm 19$ & $9-13,11 \pm 1$ & $67-86,78 \pm 4$ \\
\hline 42 & $792-882,835 \pm 24$ & $522-603,562 \pm 16$ & $9-13,11 \pm 1$ & $67-88,75 \pm 4$ \\
\hline 45 & $720-873,767 \pm 34$ & $504-603,552 \pm 20$ & $9-12,11 \pm 1$ & $60-82,70 \pm 5$ \\
\hline F test value,$p$ & $181.8, \mathrm{p}<0.05$ & $75.2, \mathrm{p}<0.05$ & $5.7, \mathrm{p}<0.05$ & $61.8, \mathrm{p}<0.05$ \\
\hline \multicolumn{5}{|c|}{ C. hispida } \\
\hline 38 & $414-603,530 \pm 39$ & $288-459,350 \pm 32$ & $9-11,10 \pm 1$ & $44-60,53 \pm 4$ \\
\hline 30 & $594-747,670 \pm 48$ & $315-702,430 \pm 81$ & $10-13,11 \pm 1$ & $56-77,63 \pm 5$ \\
\hline 40 & $657-882,801 \pm 51$ & $360-522,458 \pm 38$ & $11-14,12 \pm 1$ & $58-103,66 \pm 8$ \\
\hline 42 & $549-801,720 \pm 66$ & $333-495,437 \pm 38$ & $10-12,11 \pm 1$ & $52-103,67 \pm 11$ \\
\hline 40 & $468-684,639 \pm 42$ & $297-477,412 \pm 33$ & $10-13,10 \pm 1$ & $33-81,64 \pm 8$ \\
\hline 43 & $540-819,668 \pm 84$ & $315-522,407 \pm 52$ & $8-14,12 \pm 2$ & $43-69,59 \pm 7$ \\
\hline 46 & $558-684,626 \pm 39$ & $306-486,373 \pm 41$ & $9-12,10 \pm 1$ & $33-82,64 \pm 9$ \\
\hline 35 & $594-855,757 \pm 62$ & $405-603,495 \pm 53$ & $10-14,13 \pm 1$ & $47-69,63 \pm 5$ \\
\hline 33 & $603-774,695 \pm 51$ & $351-540,462 \pm 60$ & $7-12,11 \pm 1$ & $47-90,66 \pm 8$ \\
\hline 39 & $657-783,699 \pm 26$ & $387-522,469 \pm 31$ & $9-12,11 \pm 1$ & $56-93,68 \pm 7$ \\
\hline F test value, $p$ & $60.1, \mathrm{p}<0.05$ & $27.4, p<0.05$ & $21.5, \mathrm{p}<0.05$ & $11.4, \mathrm{p}<0.05$ \\
\hline \multicolumn{5}{|c|}{ C. intermedia } \\
\hline 36 & $657-810,744 \pm 41$ & $306-540,470 \pm 52$ & $10-12,11 \pm 1$ & $67-103,76 \pm 9$ \\
\hline 38 & $576-828,704 \pm 60$ & $324-567,425 \pm 57$ & $10-13,12 \pm 1$ & $52-86,66 \pm 8$ \\
\hline 35 & $558-873,677 \pm 61$ & $306-675,462 \pm 65$ & $9-14,10 \pm 1$ & $58-103,74 \pm 10$ \\
\hline 31 & $495-774,637 \pm 85$ & $306-486,389 \pm 49$ & $10-13,12 \pm 1$ & $47-86,57 \pm 11$ \\
\hline 39 & $540-810,678 \pm 57$ & $333-531,426 \pm 53$ & $9-12,10 \pm 1$ & $43-86,63 \pm 10$ \\
\hline 35 & $630-792,690 \pm 40$ & $315-531,440 \pm 51$ & $10-13,11 \pm 1$ & $52-77,62 \pm 6$ \\
\hline 32 & $558-720,656-44$ & $315-504,447 \pm 47$ & $7-11,10 \pm 1$ & $60-86,68 \pm 6$ \\
\hline 35 & $585-801,717 \pm 68$ & $378-558,476 \pm 41$ & $9-13,12 \pm 1$ & $43-77,61 \pm 7$ \\
\hline 40 & $693-837,775 \pm 25$ & $414-531,484 \pm 20$ & $10-13,11 \pm 1$ & $57-83,70 \pm 6$ \\
\hline 48 & $720-828,778 \pm 39$ & $432-540,500 \pm 24$ & $10-12,11 \pm 1$ & $62-76,68 \pm 4$ \\
\hline F test value, $p$ & $22.7, p<0.05$ & $14.1, \mathrm{p}<0.05$ & $18.1, \mathrm{p}<0.05$ & $17.6, \mathrm{p}<0.05$ \\
\hline \multicolumn{5}{|c|}{ C. polyacantha } \\
\hline 38 & $567-756,663 \pm 50$ & $315-477,399 \pm 44$ & $11-14,12 \pm 1$ & $22-59,46 \pm 12$ \\
\hline 30 & $486-828,731 \pm 77$ & $279-486,386 \pm 52$ & $10-12,11 \pm 2$ & $23-83,53 \pm 14$ \\
\hline 30 & $585-819,701 \pm 72$ & $288-585,434 \pm 98$ & $11-15,13 \pm 1$ & $52-71,62 \pm 5$ \\
\hline 38 & $630-756,698 \pm 35$ & $369-531,434 \pm 35$ & $10-14,13 \pm 1$ & $52-103,61 \pm 10$ \\
\hline
\end{tabular}


Table 2 Cont.

\begin{tabular}{ccccc}
\hline 31 & $585-900,716 \pm 82$ & $315-549,429 \pm 65$ & $10-17,13 \pm 2$ & $43-65,58 \pm 6$ \\
\hline F value, $\mathrm{p}$ & $5.3, \mathrm{p}<0.05$ & $3.5, \mathrm{p}<0.05$ & $8.6, \mathrm{p}<0.05$ & $11.9, \mathrm{p}<0.05$ \\
\hline \multicolumn{5}{c}{ C. rudis } \\
35 & $702-792,753 \pm 20$ & $414-732,460 \pm 62$ & $11-13,12 \pm 1$ & $53-69,59 \pm 4$ \\
30 & $585-819,701 \pm 72$ & $288-585,434 \pm 96$ & $11-15,13 \pm 1$ & $52-71,62 \pm 5$ \\
38 & $639-760,700 \pm 30$ & $360-534,431 \pm 32$ & $11-14,13 \pm 1$ & $58-103,74 \pm 10$ \\
37 & $621-765,702 \pm 37$ & $315-594,472 \pm 61$ & $11-13,12 \pm 1$ & $56-103,64 \pm 9$ \\
30 & $630-855,760 \pm 62$ & $315-594,455 \pm 96$ & $10-16,12 \pm 1$ & $52-86,65 \pm 8$ \\
39 & $558-873,677 \pm 61$ & $360-540,434 \pm 42$ & $10-14,12 \pm 1$ & $49-73,63 \pm 5$ \\
\hline F test value, $\mathrm{p}$ & $697-792,758 \pm 25$ & $441-540,496 \pm 24$ & $9-12,11 \pm 1$ & $60-77,66 \pm 5$ \\
\hline
\end{tabular}

${ }^{1} \min -\max$, mean $\pm \mathrm{SD}$ and ANOVA $F$ test for multiple comparisons. All measurements are in microns excl. number of striae.

Table 3. Least significant difference (LSD) test for multiple comparisons ${ }^{1}$.

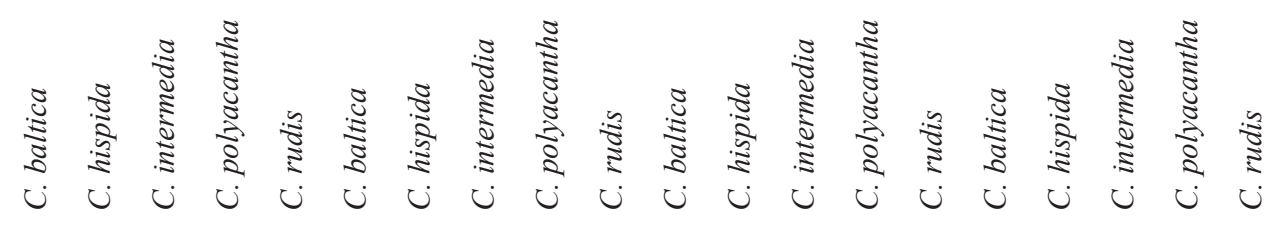

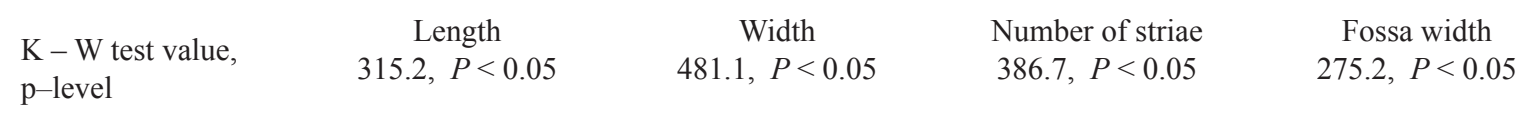

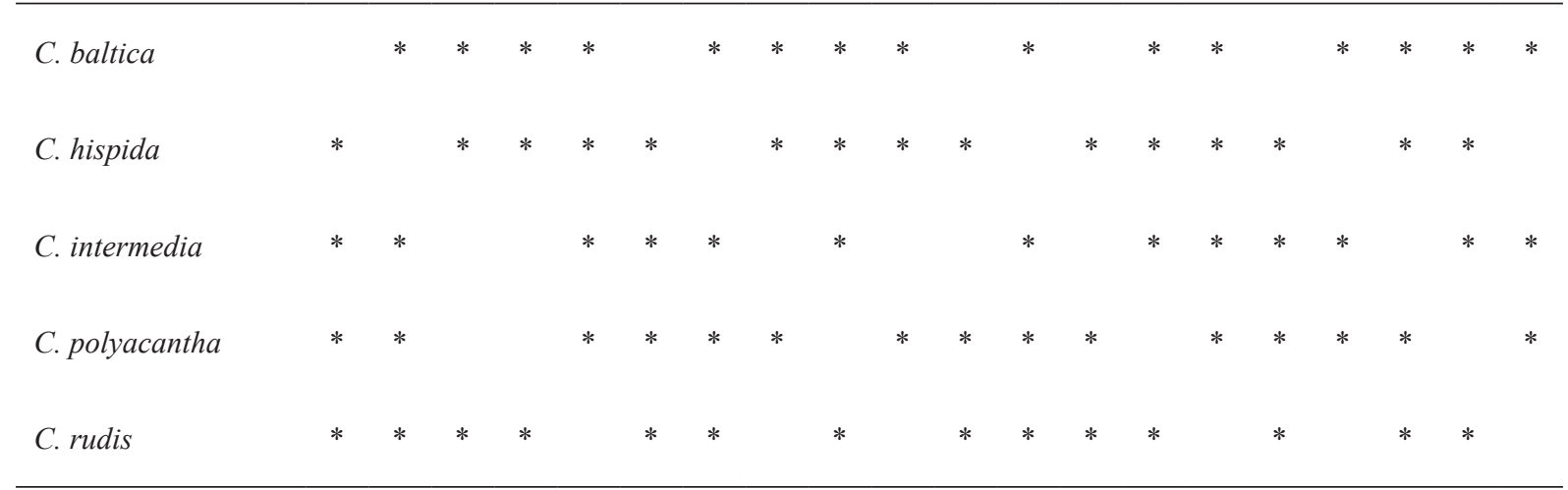

${ }^{1}$ The values labeled by “*” are significantly different at $P<0.05$.

Taxonomic accounts of species of the section Hartmania

Wood \& IMAHori (1965) assigned $C$. polyacantha, $C$. rudis, C. intermedia and C. baltica as forms of C. hispida based on the similarity in vegetative morphology. LSD post hoc tests for multiple comparisons showed that oospores of $C$. baltica differed clearly from $C$. hispida, as well as the other species (C. polyacantha, $C$. rudis and $C$. intermedia) (Table 3 ). This was confirmed by the present cluster analysis, in which C. bal- tica formed a separate branch (Fig. 3). SEM analysis of the oospore wall showed only small differentiation, which has been observed previously (URBANIAK 2010) on several oospores from species of the section Hartmania, but was confirmed based on a much larger data set in the present study. The present SEM observations of the oospore wall revealed that the fossa wall ornamentations of studied populations are similar to those in URBANIAK (2011a), but different from those in RAY et al. (2001) and LeITCH et al. (1990), who found that 


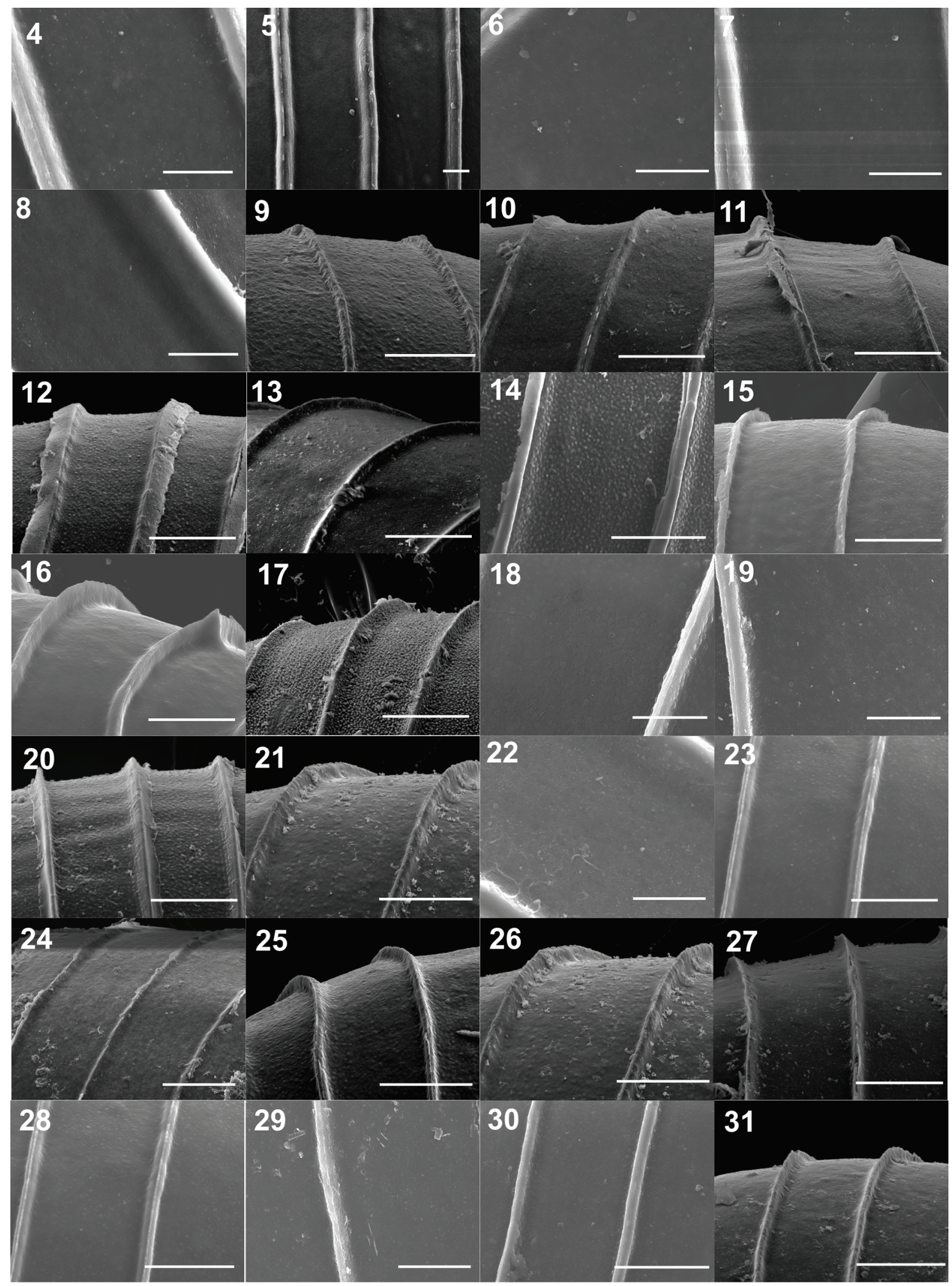

Figs 4-31. Oospore wall ornamentation of examined Chara species: (4-8) smooth oospore ornamentation of C. baltica; (9-18) oospores of C. hispida, $(9,10,12,14)$ pustular ornamentation, (11) slightly pitted ornamentation, (13) slightly granulate ornamentation, (15) slightly pustular ornamentation, $(16,18)$ smooth ornamentation, $(17)$ granulate ornamentation; $(19-23)$ oospores of $C$. intermedia, $(19,22)$ slightly granulate ornamentation, (20) pustular ornamentation, (21) slightly pustular ornamentation, (23) smooth ornamentation; (24-28) oospores of $C$. intermedia; $(24,27,28)$ smooth ornamentation, (25) pustular ornamentation, (26) slightly pustular ornamentation; (29-31) oospores of $C$. polyacantha, $(29,30,31)$ smooth ornamentation. Scale bars $20 \mu \mathrm{m}$ (Figs 4-8, 18-19, 22), $50 \mu \mathrm{m}$ (Figs 9-17, 20-21, 23-31). 


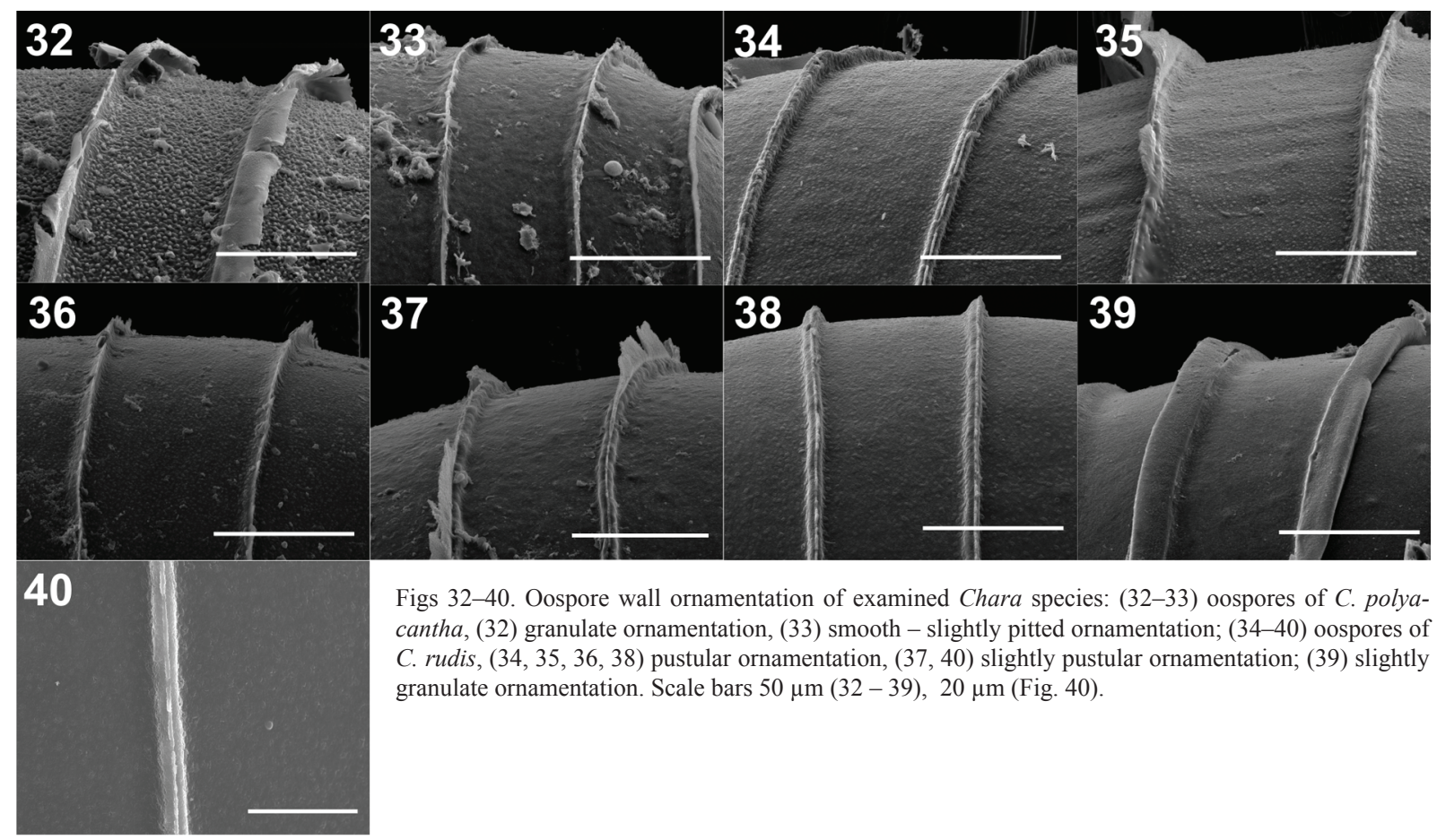

the fossa walls are porate, pitted, or with roughened surface (pits pores, depressions). However, these studies used higher magnification $(\times 15000-20000)$ that probably resulted in different images of the surface structure. Lack of significant differences in wall ornamentation among various populations of this species indicates that the smooth pattern of oospore walls is stable within this species. The pustular, slightly pustular, granulate, or slightly granulate ornamentation can be found on oospores in different species, except for $C$. baltica that exhibits a smooth pattern of oospore wall (Fig. 4-8). This indicates that $C$. baltica can be clearly distinguished from the other four species ( $C$. hispida, $C$. polyacantha, $C$. rudis and $C$. intermedia) based on oospore wall ornamentation (MANNSCHRECK et al. 2002; Blume et al. 2009; Boegle et al. 2010).

C. baltica is a truly brackish water species and occurs in the enclosed area of the Baltic Sea, with some disjunctive localities in Southern France (BLuEMEL 2003). The salinity seems to be important because, according to Winter et al. (1996) and Boegle et al. (2007), single Chara species can differ considerably with reference to their salinity preferences. This seems to be true not only for $C$. baltica, but for other brackish water species such as $C$. horrida, which can explain the close relationship between these species when determined by both physiological and morphological features (Winter et al. 1996; Boegle 2007; UrbaniaK 2010). Unfortunately, our molecular phylogeny did not support the independence of $C$. baltica within the species of the section Hartmania (Fig. 41-42). However, NowAK et al. (2016) were able to separate C. baltica and $C$. horrida on a much larger molecular data set, confirming that both species are rather independent taxa, than forms of $C$. hispida according to Wood \& IMAHORI (1965).

Statistical analyses of oospore measurements showed statistically significant differences between $C$. hispida and C. rudis in oospore length, number of striae, and fossa width (Table 3), but despite this, cluster analysis based on oospore dimensions showed a close relationship between them (Fig. 3). Moreover, SEM analyses revealed that their oospore wall ornamentations were mostly smooth at low magnification and pustular, papillate, or roughened at high magnification, confirming that there are no significant differences of the oospore wall ornamentation between these two species (URBANIAK 2011a; RAY et al. 2001). Additionally, URBANIAK (2010) showed that all of the 14 characteristics of the oospore dimensions scored for C. hispida and $C$. rudis had overlapping ranges and no distinct groups could be found. Previously, based on the AFLP method, URBANIAK \& COMBIK (2013) concluded that it is not possible to differentiate both taxa as distinct, which has been confirmed again by presented phylogenetic analyses (Fig. 41-42), as well as by NowAK et al. (2016). As all available data support this close taxonomic relationship, along with historic suggestions to place $C$. rudis as a variety of $C$. hispida (Wood \& IMAHORI 1965) and the results of URBANIAK \& COMBIK (2013), C. rudis sensu Krause (1997) should, therefore, be referred to as C. hispida f. rudis sensu WooD \& IMAHORI (1965).

Statistical analyses of oospore dimensions showed that oospores of $C$. polyacantha and $C$. intermedia were distinctive within the species analysed in this study (Table 2). However, our SEM observations of the oospore wall of both species did not show any 
C. hispida, C. rudis and C. baltica (Fig. 41). On the other hand, our mat $\mathrm{K}$ phylogeny revealed that there are two haplotypes in $C$. polyacantha and $C$. intermedia, respectively, and these two species do not constitute an independent lineage (Fig. 42). More detailed analyses based on more rapidly evolving molecular markers, using a large number of specimens, are needed to resolve their natural relationships.

\section{Molecular phylogeny and genetic variations among} species of section Hartmania

Our matK phylogeny clearly revealed that the species of section Hartmania are monophyletic, whereas the monophyly of this section was not supported in the atpB phylogeny (Fig. 41-42). This might be caused by the lack of differences in nucleotide sequences of the $a t p \mathrm{~B}$ gene, because the mat $\mathrm{K}$ gene generally evolves faster than atpB (SANDERs et al. 2003). The results of characteristic ornamentation (Fig 19-33). JoHN et al. (1990) reported that the oospore wall ornamentation of $C$. intermedia is pustular, often perforated by pores or fissures. Conversely, URBANIAK (2011a) and RAY et al. (2001) showed that $C$. intermedia has a smooth or slightly pustular ornamentation. In C. polyacantha, pustular oospore walls perforated by a fissure were reported by JOHN et al. (1990), whereas URBANIAK (2011a) showed that this species has a smooth ornamentation on the oospore wall. The smooth, pustular, or slightly granulate ornamentation found in this study was also observed by URBANIAK (2011a) and in another species belonging to the section Hartmania. Our cluster analysis indicated the existence of two separate species, rather than one single species with adequate variations (Fig. 3). In atpB phylogeny, C. polyacantha was distinguished from other species of the section Hartmania, whereas C.intermedia has an identical sequence with

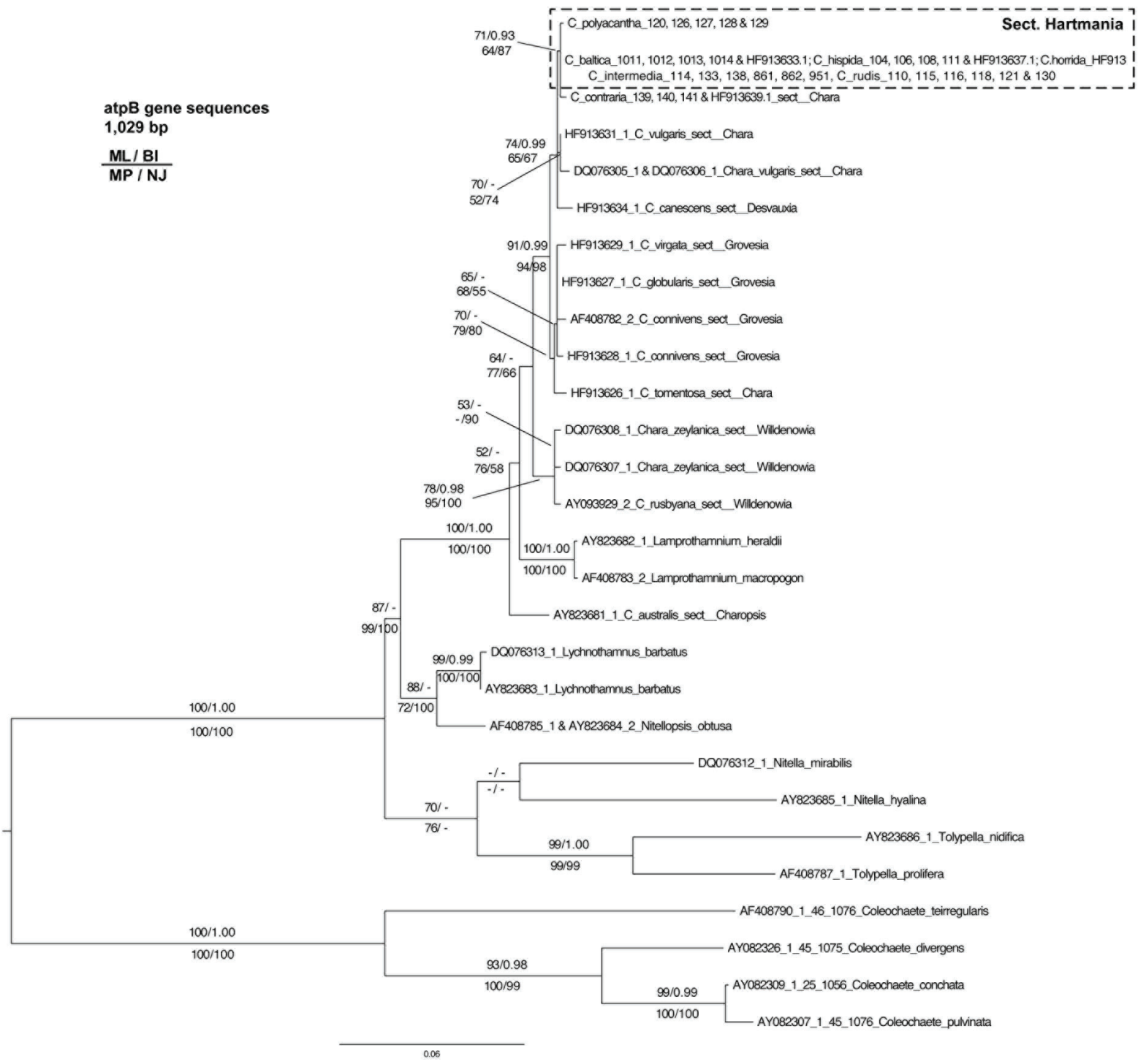

Fig. 41. Phylogenetic tree interferred from the maximum-likelihood (ML) analysis based on the atpB DNA sequence data for the Characeae and outgroup taxa. The bootstrap proportions ( $\geq 50 \%$ ) from $\mathrm{ML}$ (top left), maximum parsimony (bottom left), and neighbour-joining (bottom right) analyses are shown. The corresponding posterior probabilities $(\geq 0.90)$ are shown (top right). Branch lengths are proportional to the amount of sequence changes. The classifications of the sections given by Wood \& Imahori (1965) are shown. 
mat $\mathrm{K}$ phylogeny are in agreement with results received by NowAK et al. (2016), expectations about close phylogenetic relationships, and close evolutionary history among studied species. Definitely, from the five species studied from sect. Hartmania, C. hispida and C. rudis should be treated as one taxon, rather than separately.

It is difficult to attempt to clearly state the taxonomic relationships of representative species of the section Hartmania. Numerous morphological and molecular results such as AFLP or sequencing data indicate a very close relationship between species belonging to this section (URBANIAK 2011a; UrBANIAK \& Combik 2013; Schneider et al. 2015; SCHNEIDER et al. 2016). The precise distinction between the tested species based on morphological features is possible using quantitative characteristics, rather than descriptive characteristics (KRAUSE 1997; URBANIAK \& COMBIK 2013; URBANIAK \& GAqMBKa 2014). All of the species from the section Hartmania likely share a common line of development delivered from the common ancestor. The presence of mesohaline species like C. baltica and C. horrida, is an example of adaptation to the salty water of the Baltic Sea. For over 10,000 years, the Baltic Sea has been alternately filled with fresh and salt water, contributing to the evolution of complex organisms inhabiting them, including the Characeae. This can be regarded as a successful adaptation of the original secondary freshwater species into a saltwater habitat. Such short-term adaptive capacity has even been found experimentally by WINTER et al. (1996), who stated that euryhaline and halophobic species within the same genus is a result of evolutionary adaptations of euryhaline ancestors to unstable environments on one hand and to the stable environments of deep, freshwater bodies on the other hand. In a few cases, freshwater species could have lost the original ability to regulate turgor and developed a transport system, which maintains the osmotic potential of the cell at a constant level (WINTER et al. 1996; KAMIYA \& KURODA 1956). Another type of fast physiological adaptation to light has been found by SCHNEIDER et al. (2006), which confirms the rapid adaptation skills of species from the genus Chara. Such a situation can certainly be the case with brackish water species, such as C. baltica or C. horrida, that occur in salinities from 2-15 PSU.

Based on the obtained results, we can conclude that oospore and molecular data do not allow for a clear confirmation of the close taxonomical relations between taxa from the genus Chara, sect. Hartmania, and do not fully support either species concept of WoOd \& IMAHORI (1965) or Krause (1997). NowAK et al. (2016) point out that this is due to incomplete reproductive isolation. It is also possible that all species from sect. Hartmania, using the taxonomic system of WoOD \& IMAHORI (1965) or KrAuse (1997), had a common ancestor and thus, the species are not able to

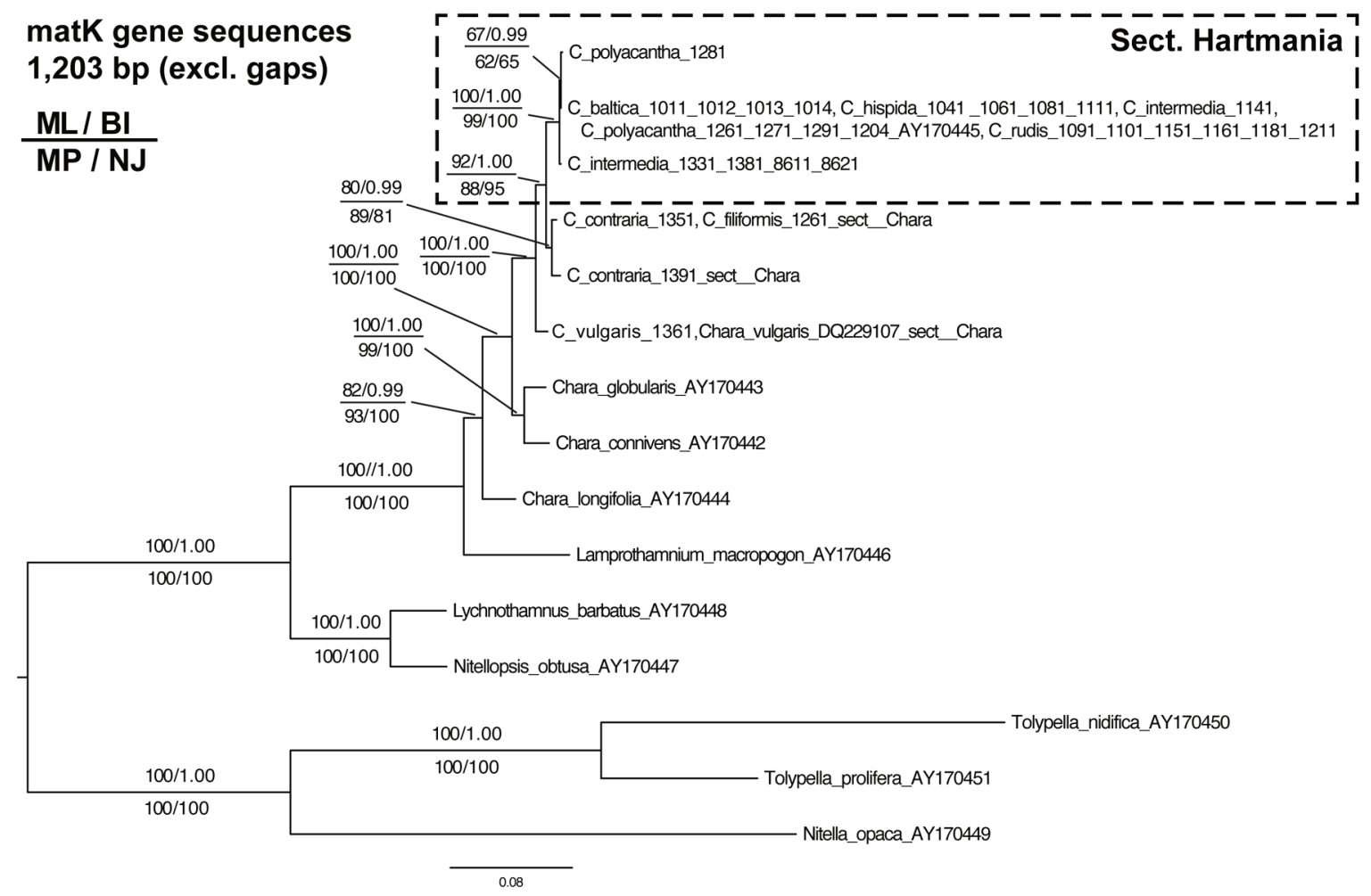

Fig. 42. Phylogenetic tree interferred from the maximum-likelihood (ML) analysis based on the matK DNA sequence data for the genus Chara and outgroup taxa. The bootstrap proportions ( $\geq 50 \%$ ) from ML (top left),,rmaximum parsimony (bottom left), and neighbour-joining (bottom right) analyses are shown. Branch lengths are proportional to the amount of sequence changes. The classifications of the sections given by Wood \& Imahori (1965) are shown. 
be distinguished using the numerous morphological or molecular methods currently available. The most recent potential common ancestor existed probably for C. rudis and C. hispida sensu Krause (1997), as indicated by their morphological and molecular similarity; both species should definitely not be treated as separate taxa.

\section{ACKNOWLEDGMENTS}

The author would like to thank Anna Latkiewicz for help with SEM analysis and Karolina Bojar, Magdalena Drill, Karolina Siemionko and Katarzyna Zając for help with oospore measurements. Maciej Gabka has helped with the material collection and Maryla Kwiatkowska with molecular analysis. This study was financially supported by the Polish Ministry of Science and Higher Education, project number: N N303 506238.

\section{REFERENCES}

Abascal, F.; Zardoya, R. \& Telford, M.J. (2010): TranslatorX, multiple alignment of nucleotide sequences guided by amino acid translations. - Nucleic Acids Research 38: 7-13.

Blume, M.; Blindow, I.; Dahlke, S. \& Vedder, F. (2009): Oospore variation in closely related Chara taxa. Journal of Phycology 45: 995-1002.

Bluemel, C. (2003): Chara baltica Wahlst. 1862. In: Schubert H, BLindow I. (eds): Charophytes of the Baltic Sea. pp. $53-63$, Gantner, Ruggell.

Boegle, M.G.; Schneider, S.; Mannschreck, B. \& Melzer, A. (2007): Differentiation of Chara intermedia and C. baltica compared to C. hispida based on morphology and amplified fragment length polymorphism. Hydrobiologia 586: 155-166.

Boegle, M.G.; Schneider, S.C.; Schubert, H. \& Melzer, A. (2010): Chara baltica Bruzelius 1824 and Chara intermedia A. Braun 1859 - distinct species or habitat specific modifications? - Aquatic Botany 93: 195201.

Braun, A. \& Nordsteadt, C.F.O. (1882): Fragmente einer Monographie der Characeen. Nach den hinterlassenden Manuscripten A. Braun's. - Abhandlungen der Königlichen Akademie der Wissenschaften zu Berlin, Physikalisch-Mathematische Klasse 1882: $1-221$.

CASANOva, M.T. (1997): Oospore variation in three species of Chara (Charales, Chlorophyta). - Phycologia 36: 274-80.

CASANOva, M.T. (2015): Chromosome numbers in Australian charophytes (Characeae, Charophyceae). - Phycologia 54: $149-160$.

Cimino, M.T. \& Delwiche, C.F. (2002): Molecular and morphological data idetify a cryptic species complex in endophytic members of the genus Coleochaete Bréb. (Charophyta: Coleochaetaceae). - Journal of Phycology 38: 1213-1221.

EDGAR, R.C. (2004a): MUSCLE, a multiple sequence alignment method with reduced time and space complexity. - BMC Bioinformatics 5: 113.

EDGAR, R.C. (2004b): MUSCLE, multiple sequence alignment with high accuracy and high throughput. - Nucleic Acids Research 32: 1792-1797.
ErdtMan, G. (1960): The acetolysis method. - Svensk Botanisk Tidskrift 54: 561-564.

Felsenstein, J. (1985): Confidence limits on phylogenies, an approach using bootstrap. - Evolution 38: 16-24.

Guindon, S. \& Gascuel, O. (2003): A simple, fast, and accurate algorithm to estimate large phylogenies by maximum likelihood. - Systematic biology 52: 696-704.

HAAS, J.N. (1994): First identification key for charophyte oospores from central Europe. - European Journal of Phycology 29: 227-235.

Horn af Rantizen, H. (1956): Morphological terminology relating to female charophyte gametangia and fructifications. - Botaniska Notiser 109: 212-259.

John, D.M. \& Moore, J.A. (1987): An SEM study of some oospore Nitella species (Charales, Chlorophyta) with descriptions of wall ornamentation and an assessment of its taxonomic importance. - Phycologia 26: 334-355.

John, D.M.; Moore, J.A. \& Green, D.R. (1990): Preliminary Observations on the Structure and Ornamentation of the Oosporangial Wall in Chara (Charales, Chlorophyta). - British Phycological Journal 25: 1-24.

Jukes, T.H. \& CANTOR, C.R. (1969): Mammalian Protein Metabolism. - In: MunRo M.N. (ed.): Evolution of protein molecules. - pp. 21 - 132, Academic Press, New York.

KamiYa, N. \& KuRODA, K. (1956): Artificial modification of the osmotic pressure of the plant cell. - Protoplasma 46: 423-436.

Karol, K.G.; McCourt, R.M.; Cimino, M.T \& Delwiche, C.F. (2001): The closest living relatives of land plants. - Science 294: 2351-2353.

Krause, W. (1997): Charales (Charophceae).- In: EtTl, H.; Gaertner, G.; Heyning, H. \& Mollenhauer, D. (eds): Süßwasserflora von Mitteleuropa, Band 18. - 202 pp., Gustav Fischer Verlag, Stuttgart - Jena, Germany.

Laurin-Lemay, S.; Brinkmann, H. \& Philippe, H. (2012): Origin of land plants revisited in the light of sequence contamination and missing data. - Current biology 22: 593-594.

Leitch, A.R. (1989): Formation and ultrastructure of a complex, multilayered wall around the oospore of Chara and Lamprothamnium (Characeae). - British Phycological Journal 24: 229-236.

Leitch, A.R.; John, D.M. \& Moore, J.A. (1990): The oosporangium of the Characeae (Chlorphyta, Charales). Progress in Phycological Research 7: 213-268.

Mandal, D. K.; Blaženčić, J. \& Ray, S. (2002): SEM study of compound oospore wall ornamentation of some members of Charales from Yugoslavia, Croatia and Slovenia. - Archives of Biological Sciences, Belgrade 54: 29-34.

Mannchreck, B.; Fink, T. \& Melzer, A. (2002): Biosystematics of selected Chara species (Charophyta) using amplified fragment length polymorphism. - Phycologia 41: $657-666$.

Mattox, K.R. \& Stewart, K.D. (1984): Classification of the green algae, a concept based on comparative cytology. - In: Irvine, D.E.G. \& John D.M. (eds): Systematics of the Green Algae. - pp. 29-72, Academic Press, London and Orlando.

Meiers, S.T.; Proctor, W.V. \& Chapman, R.L. (1999): Phylogeny and biogeography of Chara (Charophyta) inferred from $18 \mathrm{~S}$ rDNA sequences. - Australian Jour- 
nal of Botany 47: 347-360.

McCourt, R.M.; Casanova, M.T.; Karol, K.G. \& Feist, M. (1999): Monophyly of genera and species of Characeae based on rbcL sequences, with special reference to Australian and European Lychnothamnus barbatus (Characeae, Charophyceae). - Australian Journal of Botany 47: 361-369.

McCourt, R.M.; Karol, K.G.; Guerlesquin, M. \& Feist, M. (1996): Phylogeny of extant genera in the family Characeae (Charales, Charophyceae) based on rbcL sequences and morphology. - American Journal of Botany 83: 125-131.

Nowak, P.; Schubert, H.; Schaible, R. (2016): Molecular evaluation of the validity of the morphological charactersof three Swedish Chara sections: Chara, Grovesia, and Desvauxia(Charales, Charophyceae). - Aquatic Botany 134: 113-119.

Nylander, J.A.A.; Ronguist, F.; Huelsenbeck, J.P. \& NieVES-Aldrey, J.L. (2004): Bayesian phylogenetic analysis of combined data. - Systematic biology 53: $47-67$.

Olsen, S. (1944): Danish Charophyta. Chorological, ecological and biological investigations. - Kongelige Danske Videnskabernes Selskabs. Biologiske Skrifter 3: $1-240$.

Perez, W.; Hall, J.; McCourt, R. \& Karol, K.G. (2014): Phylogeny of North America Tolypella (Charophyceae: charophyta) based on plastid DNA Sequences with adescription of Tolypella ramosissima sp. nov. - Journal of Phycology 50: 776-789.

Ray, S.; PekKari, S. \& Snoeiss, P. (2001): Oospore dimensions and wall ornamentation patterns in Swedish charophytes. - Nordic Journal of Botany 21: 207224.

Romanov, R.E.; Gontcharov, A.A. \& Barinova, S.S. (2015). Chara globata Mig. (Streptophyta: Charales): rare species revised. - Fottea 15: 39-50.

Ronquist, F. \& Huelsenbeck, J.P. (2003): MrBayes 3: Bayesian phylogenetic inference under mixed models. - Bioinformatics 19: 1572-1574.

SAito, N. \& NeI, M. (1987): The neighbor-joining method, a new method for reconstruction phylogenetic trees. Molecular Biology and Evolution 4: 406-425.

SAKayama, H. (2008): Taxonomy of Nitella (Charales, Charophyceae) based on comparative morphology of oospores and multiple DNA marker phylogeny using cultured material. - Phycological Research 56: 202-215.

SaKayama, H.; Hara, Y. \& Nozaki, H. (2004): Taxonomic re-examination of six species of Nitella (Charales, Charophyceae) from Asia, and phylogentical relationships within the genus based on rbcL and atpB gene sequences. - Phycologia 43: 91-104.

Sakayama, H.; Kai, A.; Nishiyama, M.; Watanabe, M.M.; Kato, S.; Ito, M.; Nozaki, H. \& Kawai, H. (2015): Taxonomy, morphology, and genetic variation of Nitella flexilis var. bifurcata (Charales, Characeae) from Japan. - Phycological Research 63: 159-166.

Sakayama, H.; Kasai, F.; Nozaki, H.; Watanabe, M.M.; KaWachi, M.; Shigyo, M.; Nishiniro, J.; Washitani, I.; Krienitz, L. \& Ito A.M. (2009): Taxonomic reexamination of Chara globularis (Charales, Charophyceae) from Japan based on oospore morphology and rbcL gene sequences, and the description of C. leptospora sp. nov. - Journal of Phycology 45: 917-927.
Sakayama, H.; Miyaji, K.; Nagumo, T.; Kato, M.; Hara, Y. \& Nozaki, H. (2005): Taxonomic reexamination of 17 species of Nitella subgenus Tieffallenia (Charales, Charophyceae) based on internal morphology of the oospore wall and multiple DNA marker sequences. Journal of Phycology 41: 195-211.

SAKayama, H.; Nozaki, H.; Kasaki, H. \& Hara, Y. (2002): Taxonomic re-examination of Nitella (Charales, Charophyceae) from Japan, based on microscopical studies of oospore wall ornamentation and rbcL gene sequences. - Phycologia 41: 397-408.

SAnders, E.R.; Karol, K.G. \& McCourt, R.M. (2003): Occurrence of matK in a trnK group II intron in charophyte green algae and phylogeny of the Characeae. - American Journal of Botany 90: 628-633.

Schneider, S.C.; Nowak, P.; Ammon, U. \& Ballot, A. (2016): Species differentiation in the genus Chara (Charophyceae): considerable phenotypic plasticity occurs within homogenous genetic groups. - European Journal of Phycology 51: 282-293.

Schneider, S.C.; Rodrigues, A.; Moe, T.F. \& Ballot, A. (2015): DNA barcoding the genus Chara, molecular evidence recovers fewer taxa than the classical morphological approach. - Journal of Phycology 51: 367-380.

Schneider, S.C.; Ziegler, C. \& Melzer, A. (2006): Growth towards light as an adaptation to high light conditions in Chara branches. - New Phytologist 172: 83-91.

StATSoft, Inc. (2010): STATISTICA (data analysis software system). Version 9.1. Tulsa, USA.

Swofford, D.L. (2002): PAUP* - Phylogenetic Analysis Using Parsimony (*and other methods). Version 4.0b10. Sinauer Associates, Sunderland, USA.

Tanabe, A.S. (2011): Kakusan 4 and Aminosan, two programs for comparing nonpartitioned, proportional and separate models for combined molecular phylogenetic analyses of multilocus sequence data. - Molecular Ecology Resources 11: 914-921.

Thompson, J.D.; Higgins, D.G. \& Gibson, T.J. (1994): CLUSTAL W, Improving the sensitivity of progressive multiple sequence alignment through sequence weighting, position-specific gap penalties and weight matrix choice. - Nucleic Acids Research 22: $4673-4680$.

Turmel, M.; Otis, C. \& Lemieux, C. (2006): The chloroplast genome sequence of Chara vulgaris sheds new light into the closest green algal relatives of land plants. - Molecular Biology and Evolution 23: 1324-1338.

URBANIAK, J. (2009): Oospore variation in Nitella gracilis and Nitella mucronata (Charales, Charophyceae) from Poland. - Biologia 64: 252-260.

URBAniaK, J. (2010): Analysis of morphological characters of Chara baltica, C. hispida, C. horrida and C. rudis from Europe. - Plant Systematics and Evolution 286: 209-221.

URBANIAK, J. (2011a): An SEM and light microscopy study of the oospore wall ornamentation in Polish charophytes (Charales, Charophyceae) - genus Chara. Nova Hedvigia 93: 1-28.

URBANIAK, J. (2011b): An SEM study of the oospore wall ornamentation in Polish charophytes (Charales, Charophyceae) - genus Lychnothamnus, Nitella and Nitellopsis. - Nova Hedvigia 93: 537-549.

URBANIAK, J. \& BlAŽEnČIĆ, J. (2012): SEM study of oospore characteristics in endemic and endangered Balkan 
Charophytes. - Cryptogamie, Algologie 33: 277288.

UrbaniaK, J. \& CombiK, M. (2013): Genetic and morphological data fail to differentiate Chara intermedia from C. baltica, or C. polyacantha and C. rudis from C. hispida. - European Journal of Phycology 48: 253-259.

Urbaniak, J. \& Combik, M. (2017): Taxonomic status of Chara tenuspina A. Br. (Streptophyta: Charales) based on LM morphology, matK, atpB and rbcL of cpDNA sequences. - Fottea 17: 20-33.

Urbaniak, J. \& GąBKA, M. (2014): Polish Charophytes. An illustrated guide to identification. - 120 pp., Wydawnictwo Uniwersytetu Przyrodniczego we Wrocławiu, Wrocław.

Urbaniak, J.; Langangen, A. \& RaAm, J. (2012): Oospore Wall Ornamentation in the Genus Tolypella (Charales, Charophyceae). - Journal of Phycology 48: 1538-1545.

Winter, U.; Soulie-Märsche, I. \& Kirst, G.O. (1996): Effects of salinity on turgor pressure and fertility in Tolypella (Characeae). - Plant, Cell and Environment 19: 869-879.

Vedder, F. (2004): Morphologie und Taxonomie rezenter und subfossiler Characeen-Oosporen aus der Ostsee. - Rostocker Meeresbiologishe Beitrage 13: 43-54.

Wodniok, S.; Brinkmann, H.; Glöckner, G.; Heidel, A.J.; Philippe, H.; Melkonian, M. \& Becker, B. (2011): Origin of land plants, do conjugating green algae hold the key? - BMC Evolutionary Biology 11: 104.

Wood, R.D. (1962): New combinations and taxa in the revision of Characeae. - Taxon 11: 7-25.

Wood, R.D. \& ImAHoRI, K.A. (1965): A revision of the Characeae. First part, Monograph of the Characeae. - 904 pp., J. Cramer Verlag, Weinheim.

(C) Czech Phycological Society (2017)

Received October 26, 2016

Accepted January 31, 2017 